Notre Dame Law School

NDLScholarship

Journal Articles

Publications

1977

\title{
Abortion and Constitution: United States and West Germany
}

Donald P. Kommers

Notre Dame Law School, donald.p.kommers.1@nd.edu

Follow this and additional works at: https://scholarship.law.nd.edu/law_faculty_scholarship

Part of the Comparative and Foreign Law Commons, Health Law and Policy Commons, and the Law and Gender Commons

\section{Recommended Citation}

Donald P. Kommers, Abortion and Constitution: United States and West Germany, 25 Am. J. Comp. L. 255 (1977).

Available at: https://scholarship.law.nd.edu/law_faculty_scholarship/18

This Article is brought to you for free and open access by the Publications at NDLScholarship. It has been accepted for inclusion in Journal Articles by an authorized administrator of NDLScholarship. For more information, please contact lawdr@nd.edu. 


\section{Abortion and Constitution: United States and West Germany}

\section{INTRODUCTION}

On 22 January 1973 the U.S. Supreme Court substantially curtailed the power of the American states to prohibit or limit the right of a woman to procure an abortion. ${ }^{1}$ On 25 February 1975, the West German Federal Constitutional Court ruled that the German Parliament, by permiting abortions within the first three months of pregnancy, violated the constitutional rights of unborn children. ${ }^{2}$ These decisions provide us with an uncommon opportunity to compare the constitutional law of different nations on abortion. That the highest tribunals of two robust constitutional democracies and secular political cultures should decide differently the question of the unborn child's right to life under the constitutions of their respective countries must excite curiosity, no matter one's stand or stake in the abortion controversy.

This article seeks to restate and assess the reasoning in support of the doctrinal results in the German and American cases and then to relate those results to the legal cultures and constitutional values of the two countries. Yet we cannot wholly separate the two decisions from their political contexts or from the debate, intense in both countries, about the role of the judiciary in their respective systems of government. In both countries the very propriety of judicial intervention in the policy-making process on abortion has been severely deplored. In fact, the issue of the judiciary's role in the making of abortion policy received considerable stress by the dissenting justices of both tribunals. Thus we cannot afford to ignore the issue here.

Donald P. Kommers is Director, Center for Civil Rights, University of Notre Dame. The author wishes to thank Professor Dr. Hans Verweyen (Essen University, West Germany) and Professor Walter F. Murphy (Princeton University) for their valuable comments and suggestions on an earlier draft of the paper. The author is also grateful to Mr. Michael J. Wahoske, Research Assistant in the Center for Civil Rights of the University of Notre Dame Law School, for his generous assistance and meticulous workmanship.

1. See 410 U.S. 113 (1973) and 410 U.S. 179 (1973).

2. Judgment of 25 Feb. 1975,39 BVerfG 1-95 (1975). The decisions of the Federal Constitutional Court are reported in Entscheidungen des Bundesverfassungsgerichts (1952-date). The official abbreviation of these reports is BVerfG. 
Democracy and constitutionalism, although capable of creatively coexisting within the same political order, are principles with a frequent aversion for one another. The tension between these principles is clear in the abortion cases. The ruling in both regimes represents a judicial veto of legislative policy. In the United States and West Germany, however, judicial authorities are empowered to review statutes on constitutional grounds and if they find, in a case properly before them, that an act of the legislature is in conflict with the Constitution, they may nullify the act or refuse to enforce it. In a regime of judicial review, authority of the judiciary to void legislation raises serious questions about the relationship between courts and legislatures, particularly since the line separating constitutionality and unconstitutionality is thin and often the source of lively dispute between fair and reasonable men. A full comprehension of the abortion decisions will require some further mention of this relationship in the two political systems together with some discussion of the legal rules governing the jurisdiction of the deciding tribunals.

\section{BACKGROUND}

\section{A. The United States}

Roe v. Wade and Doe v. Bolton involved litigants in Texas and Georgia who challenged on federal constitutional grounds their respective state statutes limiting the right of a woman to obtain a legal abortion. ${ }^{3}$ These statutes were typical of most state laws on abortion. The Texas law prohibited abortion unless procured by medical advice for the purpose of saving the life of the mother. ${ }^{4}$ When Wade and Bolton were decided, the criminal abortion laws of a majority of states were similarly restrictive. For the most part, these laws were carbon copies of state statutes enacted in the early nineteenth century.

Georgia's statute, patterned after the American Law Institute's Model Penal Code, ${ }^{5}$ was of more recent vintage. Revised in 1968 , it limited legal abortions to situations where (1) a continuation of the pregnancy would endanger the life or seriously and permanently injure the health of the pregnant woman, (2) the fetus would very likely be born with a grave, permanent, and irremediable mental or physical defect, or (3) the pregnancy resulted from forcible or statutory rape. Among the statute's procedural and evidentiary provisions was the requirement of a written medical opinion by a physician stating that an abortion is justified under the statute along with the written concurrence in that opinion of at least two other physicians licensed to practice medicine in Georgia. ${ }^{\theta}$

\footnotetext{
3. Supra n.1.

4. See Tex. Pen. Code Ann., Arts 1191-96 (1961).

5. Model Penal Code, sec. 2303 (Proposed Official Draft, 1962).

6. Ga. Code Ann., sec. 26-1202 (1972).
} 
Prior to the Supreme Court's holding in these cases, abortion was a criminal offense in all the American states. Historically, the social judgments which these laws embodied enjoyed a firm mooring in the nation's moral consciousness. But within a relatively short period of time, roughly during the 1960 's, public support for restrictive abortion laws seemed dramatically to erode, although today's public opinion polls still show substantial minority support for such laws. More important was the reversal in educated American opinion, particularly within the legal and medical communities, which probably laid the foundation for the liberalization of some state abortion laws, notably that of New York, effectively allowing abortion on demand up to the 24th week of pregnancy.?

Another striking instance of this shift in influential opinion was the 1972 report of the President's Commission on Population Growth, which recommended that abortion be readily available in all the states. $^{8}$ Yet in spite of such pronouncements and in the face of mounting opposition to restrictive abortion statutes, state legislators generally held firm in their conviction that existing laws were not only a fair accommodation between the interests of pregnant women and unborn children, but also a reflection of predominant moral feeling among their constituents. Wade and Bolton came to the Supreme Court within this general context of continuing state legislative support of policies proscribing abortion. Wade involved a pregnant single woman, Bolton an indigent, married, pregnant woman, both of whom sought declaratory judgments that their respective state abortions laws (Texas and Georgia) were unconstitutional.

Some commentators have strenuously argued that the Supreme Court exceeded its rightful authority in reaching the merits of Wade and Bolton, for the female litigants had already terminated their pregnancies-rendering their cases moot in the eyes of the Court's criticsand were in no immediate danger of losing their liberty or being de-

7. N.Y. Pen. Law, sec. 125.05 (McKinney Supp., 1971).

8. See Population and the American Future, The Report of the Commission on Population Growth and the American Future 142 (1972). Leo Pfeffer offers an interesting if not wholly convincing explanation of this startling shift of opinion: "Partly it is to be found in changing standards of morality (manifested, if not to some extent caused, by Supreme Court decisions practically making pornography legal) which now seems to accept premarital sexual relations; partly the women's liberation movement and its claim that a woman has the right to decide what will happen to her own body; partly in the recognition (though hardly new) that realistically the choice is not between legal abortions and no abortions, but between safe legal ones and dangerous, sordid, illegal ones. All this is true, yet it is probable that a major factor here, as in the case of contraceptive birth control, is the taxpayer's revolt against rising welfare rolls and costs. Legalization of contraception not having worked to an acceptable degree, and other measures ... . proving too Draconian for public acceptance, permissible abortion, encouraged by the state, is the next logical step." God, Caesar, and the Constitution 99-100 (1975). 
prived of a federal constitutional right." According to this view, the parties had no "standing to sue" and were therefore incapable of invoking the Court's jurisdiction. ${ }^{10}$ However, the Court remarked in Wade that litigation involving pregnancy, which is "capable of repetition" is an exception to the federal rule that an actual controversy must exist at the time a case is decided on appeal. ${ }^{11}$ In Bolton the Court held that even licensed physicians consulted by pregnant women have standing to sue because they are within reach of the law's criminal provisions. These physicians "should not be required to await and undergo a criminal prosecution as the sole means of seeking relief," 12 asserted the Court. Thus, the abortion cases were capable of judicial resolution.

Some of the Court's critics have noted that this apparent stretching of the standing rule is the result of significant enlargement of the Court's own perception of its institutional role. They would probably agree with Richard A. Epstein's assertion that "the Supreme Court today views constitutional litigation as a means of settling great conflicts of the social order."13 On the other hand, as Tocqueville once reminded us, all great political conflicts in America tend eventually to resolve themselves into constitutional questions. ${ }^{14}$ Failing to achieve their objectives by political means, proponents of liberalized abortion laws naturally gravitated to the judiciary, seeking victory on more favorable terrain. For purposes of this analysis, however, it is not the victory that is important, but rather the Court's own capacity to persuade a reasonably open mind of the validity and propriety of its ultimate ruling.

\section{B. West Germany}

The German case provides an intriguing contrast to the American situation. First, although West Germany is a federal republic composed of ten states, excluding West Berlin, the making of abortion pol-

9. See Epstein, "Substantive Due Process by any Other Name: The Abortion Cases," The Supreme Court Review 1973 160-67 (1974).

10. Baker v. Carr, 369 U.S. 186, 204 (1962). There is a rule in American constitutional law that federal courts are powerless to adjudicate a case unless it is "presented in an adversary context and in a form historically viewed as capable of judicial resolution." This means that the judicial power of the United States can be invoked only in a concrete case (i.e. a real controversy, not a contrived or friendly suit) by a litigant who has sustained or is immediately in danger of sustaining an injury under federal law or the Constitution. Such a constraint is one way of confining the political and social roles of the federal judiciary in a manner consistent with the constitutional principle of separation of powers.

11. 410 U.S. 113,125 (1973).

12. 410 U.S. 179,188 (1973).

13. Epstein, supra n.9 at 161.

14. de Tocqueville, Democracy in America 207 (Henry Reeve transl. 1835). 
icy falls exclusively within the jurisdiction of the national government. Unlike the bulk of criminal law in the United States, the Penal Code, Section 218 of which provides penalties for illegal abortion, is national law. Originally based on the Prussian Penal Code of 1851, the current code was adopted by the German Reich in $1871 . .^{15}$ The code provisions on abortion under inspection here were associated with a major effort in Germany to revise and reform the criminal code as a whole. The Revised Penal Code went into effect on 2 January 1975. ${ }^{15 a}$

Second, the Basic Law of 1949 (Grundgesetz) confers on the Federal Constitutional Court explicit and far-reaching powers of judicial review. Among these powers is the Court's authority to resolve "differences of opinion or doubts on the formal and material compatibility of federal law or land [state] law with this Basic Law."16 This is known as an abstract judicial review proceeding (abstrakte Normenkontrolle), which can be initiated only by the Federal Government (Chancellor and Cabinet), a state government, or one third of the Bundestag's members. ${ }^{17}$ The proceeding is called "abstract" because no concrete controversy involving adverse parties engaged in litigation before the regular courts is required, as in the United States, to trigger the exercise of judicial review. Thus politicians and governments may draw the Federal Constitutional Court into their political conflicts almost at will, risking the possibility of the Court blunting government by majority rule well before the democratic process is fully played out. ${ }^{18}$ Thus a defeated legislative minority of 100 delegates or more is able, as happened in the Abortion Case, to transfer a controversy directly from the legislature to the Constitutional Court if the statute, once duly promulgated, is challenged on constitutional grounds. ${ }^{19}$

15. See German Penal Code of 1871, $\S 218$ at 114, The American Series of Foreign Penal Codes (1961).

15a. Strafgesetzbuch (StGB) in the version of 2 January 1975 (BGBl. I 1, 7 Jan. 75 at 2 ; SaBl. Nr. 5,31 Jan. 75 at 209.

16. See Basic Law for the Federal Republic of Germany (Grundgesetz), Art. $93, \S 1, \pi 2$. The provisions of the West German Basic Law relating to the authority and organization of the Federal Constitutional Court have been implemented by the Federal Constitutional Court Act of 12 March 1951 (Gesetz über das Bundesverfassungsgericht), $1951 \mathrm{BGBl}$. I 243. Hereafter the Act is cited as BVerfGG.) For a fuller discussion of the Court's authority see Kommers, Judicial Politics in West Germany: A Study of the Federal Constitutional Court 100-03 (1976).

17. BVerfGG $\S 13(6)$. There are fourteen other types of proceedings which the Court may hear under the law and the Constitution. Each requires special procedures and litigants. In only one of these proceedings-the constitutional complaint-may an individual citizen invoke the Court's jurisdiction. All other cases are brought by agencies, branches, or levels of government.

18. But in fact the Constitutional Court has exercised this jurisdiction very cautiously. Frequently, the Court will simply sit on a case and not decide it in the expectation that the initiating party will withdraw the case or that the dispute will be resolved politically before the Court decides.

19. In addition, the Abortion Reform Act was challenged in the Federal 
Such a capability would on first impression appear anomalous in a parliamentary democracy powered by a responsible party system, committed to majority rule.

Yet the Federal Constitutional Court has been one of the strongest guardians of the democratic process in West Germany, seeking to insure, for example, that the system of political representation operates to guarantee public policies reasonably in accord with the "general will."20 Since it has been alleged in some circles that the decisionmaking process here violated the principle of democratic responsibility, we should recapitulate the steps leading to the parliamentary approval of the Abortion Reform Act of 1974."1

In contrast to the United States, where long-standing abortion statutes were not the subject of extended legislative discussion prior to their sudden invalidation by the Supreme Court, the new German policy had long been preceeded by a lively national debate. Like most American state laws, the German Penal Code since the mid-nineteenth century had placed a ban on abortion however and whenever performed. The old abortion statute included the following provisions:

1. A woman who destroys her fetus or permits it to be destroyed by another shall be punished by imprisonment, and in especially serious cases by confinement in a penitentiary.

2. The attempt is punishable.

3. Any other person who destroys the fetus of a pregnant woman shall be punished by confinement in a penitentiary and in less serious cases by imprisonment.

4. Anybody who supplies a pregnant woman with a drug or object designed to destroy the fetus, shall be punished by imprisonment; and in especially serious cases by confinement in a penitentiary. ${ }^{22}$

Subject to considerable official scrutiny during the time of the Weimar Republic, this law was relaxed in its severity by a 1927 decision of the Supreme Court (Reichsgericht), which held that an abortion procured for medical reasons (medizinische Indikationen) - that is, when necessary to preserve the life and health of the pregnant womanwas not punishable under the law. ${ }^{23}$ An abortion procured by legitimate medical means to preserve the mother's life is an "extra-legal

Constitutional Court by the governments of Baden-Württemberg, Saarland, Bavaria, Schleswig-Holstein, and Rhineland-Pfalz.

20. See Kommers, "Politics and Jurisprudence in West Germany: State Financing of Political Parties," The Am. J. Jur. 215-241 (1971).

21. The Fifth Statute to Reform the Penal Law of 18 June 1974, 1974 BGB1. I 1297.

22. German Penal Code, supra n. 15 at 114.

23. Judgment of 11 March 1927, 61 RGSt (Entscheidungen des Reichgerichts in Strafsachen) 242, 
emergency" (übergesetzliche Notstand), said the Court, and can be justified within broad principles of the criminal law. ${ }^{24}$

In the 1950's another comprehensive review of abortion policy took place, culminating in the German Draft Penal Code of 1962. ${ }^{25}$ The Draft Code continued to treat abortion as a punishable offense, but lowered considerably the maximum penalty. In addition, the proposed code permitted the destruction of the fetus by a physician "if according to medical knowledge and experience, danger of death or of undue and serious injury to the body or health . . . of the woman can be averted only by the abortion."26 Under considerable pressure to liberalize abortion policy, Parliament nevertheless failed to enact these provisions into law. Indeed, there was considerable parliamentary sentiment in favor of decriminalizing abortion within the first twelve weeks of pregnancy, mainly because of the feeling among legislators that penal sanctions were of little use in deterring abortions.

Between 1965 and 1972, Parliament considered several abortion reform bills, but none commanded anything close to majority support. ${ }^{27}$ Finally, in April 1972, a special committee on criminal law reform held public hearings on two major proposals, one offering an "indications" solution and the other a "term" solution as a means of liberalizing the old abortion law. ${ }^{28}$ The first proposal, introduced by the Federal Government, would have allowed an abortion in four situations: To preserve the life and health of the mother ("medical indications"); to avert the birth of a seriously defective child ("eugenic indications"); to terminate a pregnancy caused by a sexual assault ("ethical indications"); and to unburden the woman of extremely harmful consequences that would arise in the event of the child's birth ("social indications"). In the last two situations an abortion would have been permissible only in the first trimester of pregnancy, subject to the

24. 39 BVerfG 6.

25. German Draft Penal Code, $\S 140(1)$ at 91 , The American Series of Foreign Penal Codes (1966).

26. Id., $\$ 157$ (1) at 97. It is of some comparative interest to note that similar provisions were contained in the Model Penal Code proposed by the American Law Institute in 1962. See Model Penal Code, Proposed Official Draft $\S 230.3$ (1962). Needless to say, the provisions of the Model Penal Code would be invalid under the constitutional standards of Roe $v$. Wade.

27. These details of the parliamentary debate are drawn from the Federal Constitutional Court's own account of the legislative history leading up to the passage of the Abortion Reform Act of 1974. See 39 BVerfG 6-18.

28. "Indications solution" (Indikationslösung) and "term solution" (Fristenlösung) are commonly used expressions in Germany when referring to abortion policy. These terms are awkward in English but we shall use them here anyway. An indications solution means that a pregnancy may be interrupted at any time for reasons defined by law; a term solution means that an abortion would be permitted, for whatever reason, within a given stage of pregnancy, usually within the first trimester. There has been great controversy in Germany over which is the better or more equitable solution to the abortion controversy. 
sole condition that the operation be performed by a licensed physician after the woman had submitted to professional counseling.

The second proposal-a term solution-would have rested a decision to abort a fetus entirely with the woman and her physician within the first three months of pregnancy. But even the governing coalition of the Social Democratic Party (SPD) and the Free Democratic Party (FDP) headed by Chancellor Willy Brandt felt that this measure, failing adequately to protect unborn life, was too extreme. The Christian Democratic Union (CDU) and its conservative Bavarian affiliate, the Christian Social Union (CSU), were in opposition to both bills. Thus abortion policy in West Germany, unlike the United States, became the subject of partisan controversy, with the ensuing parliamentary strife mirroring the fierce clash of opposing groups in the society at large. But a domestic economic crisis resulted in the premature dissolution of Parliament, and with the calling of new federal elections in November 1972 the legislative debate on abortion came to a sudden close.

Surprisingly, abortion reform was not debated by the contesting political parties in the 1972 election campaign. ${ }^{29}$ Social Democrats, needing Catholic votes, were especially reluctant to raise the issue, although Free Democrats occasionally spoke out in favor of a liberalized abortion law. As a consequence, the Brandt Government, even though returning to power with a substantial parliamentary majority, could not easily claim to have a popular mandate for an abortion reform policy, and none was introduced by the Government in the newly elected Parliament. Instead, four separate bills proposed by individual legislators and party groups were referred to a special committee on penal law reform. These bills included proposals ranging from a policy of abortion on demand in the early months of pregnancy, favored by a small group of SPD-FDP delegates, to an abortion policy restricted to medical indications, favored by Christian Democrats. None received majority support in the special committee, whereupon, in an unusual move, all four bills were sent to the floor of the Bundestag.

The new Abortion Reform Act of 1974, which was backed by a majority of SPD and FDP delegates, amended the Penal Code in the following ways: First, termination of a pregnancy would no longer be punishable during the first twelve weeks after conception if performed by a licensed physician with the consent of the pregnant woman ( $\$ 218 a$ ); second, destruction of the fetus would be permissible after the first twelve weeks if warranted by medical or eugenic indications and procured prior to the twenty-second week of pregnancy

29. For a detailed account of the 1972 election campaign see Heidenheimer \& Kommers, The Governments of Germany ch. 5 (4th ed. 1975). 
( $\$ 218 \mathrm{~b})$; finally, the person or physician terminating the pregnancynot the pregnant woman-would be punishable under the Act ( $\S$ 218d). Criminal penalties would continue to operate with respect to abortions performed after the third month of pregnancy, except in those instances where medical, eugenic, or ethical indications would justify the fetus' destruction..$^{30}$

We should note that those Germans who might have wished a stout parliamentary defense of the pregnant woman's right to interrupt a pregnancy would recoil before the SPD-FDP's rationale in support of the Reform Act, for the new policy was ostensibly based on a theory of deterrence. Whatever the feeling toward abortion outside Parliament, the legislative reform was not predicated on any presumed right of women flatly to terminate their pregnancies. The counseling section of the new law was simply regarded as a more effective method of turning pregnant women away from abortion and of protecting unborn life than resort to criminal sanctions. This strategy was adopted in the awareness that women, despite criminal penalties, were resorting increasingly to illegal abortion. Thus the decriminalization of abortion in the early months of pregnancy was no ringing affirmation of a female bill of rights; it merely represented an attempt by Parliament to adjust the legal order to an evolving social reality.

Even so, the Act came under instant attack, which was both political and constitutional. On the political side some Christian Democrats suggested-and this ties in with the earlier-mentioned argument based on democratic theory-that there was no mandate in support of the abortion statute. And the haste with which the bill was finally passed precluded any meaningful consultation between the Government, charged under the Basic Law with the primary responsibility of setting policy guidelines, ${ }^{31}$ and the Parliament. Moreover, as the Constitutional Court itself acknowledged, the bill failed to command majority support upon first balloting in the Bundestag, and was finally accepted by fewer than an absolute majority of delegates as the less objectionable of two proposals which survived an earlier ballot taken to eliminate those bills with least support. Thus, the bill finally approved was not the first, nor in many cases the second, choice of legislators voting for it. From the point of view of democratic theory, then, opponents of the bill could suggest that the statute did not bear the clear stamp of legitimacy marking a policy generated within a parliamentary democracy.

The more serious challenge to the Abortion Reform Act was constitutional. The ink had barely dried on the Act when the state governments of Baden-Württemberg, Bavaria, Rhineland-Pfalz, Saarland,

30. Art. 65, Basic Law (1949).

31. N. 21 supra. 
and Schleswig-Holstein-half of the German states-together with 193 members of the Bundestag-all Christian Democrats-filed petitions with the Federal Constitutional Court challenging the Act's validity under several provisions of the Basic Law. On 21 June 1974 the Court responded by issuing a temporary injunction enjoining the application of the law pending a full determination of its constitutionality.

\section{The Courts Speak}

\section{A. The American Decision}

There are several interesting steps in the Supreme Court's argument in Wade and Bolton. Speaking through Mr. Justice Blackmun, the Court first explored the historical origin of American state abortion laws. Its rather detailed excursion through history includes a description of abortion policy as reflected in Greek and Roman Law, the Hippocratic Oath, Common Law, English statutory law, and American law, followed by an analysis of the evolving policy and current attitudes of the American Medical Association, the American Public Health Association, and the American Bar Association. Without indicating precisely the relevance of its historical overview to the doctrinal point made later in the opinion, the Court then hastens into a discussion of the reasons justifying American criminal abortion statutes; after noting that most were passed in the latter half of the nineteenth century, the Court concludes that they were intended mainly for the purpose of protecting the woman from a dangerous medical procedure as well as for the purpose of preserving prenatal life..$^{32}$

Justice Blackmun then turns to a consideration of the right to privacy. Acknowledging that the Constitution does not explicitly mention any such right, he affirms its existence by implication, citing several decisions in which the Court has found in varying contexts at least the roots of that right under assorted provisions of the Constitution. The conclusion of the Court deserves to be quoted in full:

This right of privacy, whether it be founded in the Fourteenth Amendment's concept of personal liberty and restrictions upon state action, as we feel it is, or, as the District Court determined, in the Ninth Amendment's reservation of rights to the people, is broad enough to encompass a woman's decision whether or not to terminate her pregnancy. The detriment that the State would impose upon the pregnant woman by denying this choice altogether is apparent. Specific and direct harm medically diagnosable even in early pregnancy may be involved. Maternity, or additional offspring, may force upon the woman a distressful life and future. Psychological harm may be imminent. Mental and physical

32. 410 U.S. $113,130-150$ (1973). 
health may be taxed by child care. There is also the distress, for all concerned, associated with the unwanted child, and there is the problem of bringing a child into a family already unable, psychologically and otherwise, to care for it. In other cases, as in this one, the additional difficulties and continuing stigma of unwed motherhood may be involved. All these are factors the woman and responsible physician necessarily will consider in consultation. ${ }^{33}$

However, cautioned the court, the right of personal privacy is not absolute. At some point in pregnancy, wrote Justice Blackmun, "a state may assert important interests in safeguarding health, in maintaining medical standards, and in protecting potential life."34

Crucial to the outcome of the Abortion Cases was the question of whether the Fourteenth Amendment protects the unborn fetus from indiscriminate destruction. ${ }^{35}$ Justice Blackmun answered by declaring that the fetus is not a "person" within the Amendment's protection. Taking judicial notice of the historical conflict among theologians, philosophers, and physicians over the issue of the fetus' personhood, the Court simply asserted: "We need not resolve the difficult question of when life begins." ${ }_{36}$ When, then, does the state acquire a legitimate interest in protecting "potential life?" Approximately at the end of the second trimester of pregnancy, when the fetus has become viable, answers the Court. At this stage, the state "may, if it chooses, regulate, and even proscribe, abortion except where it is necessary, in appropriate medical judgment, for the preservation of the life or health of the mother." 37 At the end of the first trimester the state may begin to regulate the abortion procedure in the interest of promoting the health of the mother, but it may not constitutionally prohibit abortions altogether. During the first trimester the state is powerless to assert any legitimate interest in regulating abortion: at this stage the woman's right to privacy is predominant; the abortion decision "must be left to [her and] the medical judgment of the pregnant woman's attending physician."38

Dissenting opinions were written by Justices White and Rehnquist. In one of his strongest dissents ever, Justice White described the majority opinion as "an exercise in raw judicial power," one which effectively upholds, and imposes upon the states, a policy of abortion

33. Id. at 153 .

34. Id. at 154 .

35. According to $\S 1$ of the Fourteenth Amendment: "No State shall make or enforce any law which shall abridge the privileges or immunities of citizens of the United States; nor shall any state deprive any person of life, liberty, or property, without due process of law; nor deny to any person within its jurisdiction the equal protection of the laws."

36. 410 U.S. 113, 159 (1973).

37. Id. at 165 .

38. Id. at 164 . 
on demand. "The Court simply fashions and announces a new constitutional right for pregnant mothers and with scarcely any reason or authority for its action, invests that right with sufficient substance to override most existing state abortion statutes." 30 In White's view, the Court had merely substituted its values with respect to the ordering of priorities between mother and unborn child for those of the states, a policy which "should be left with the people and to the political processes the people have devised to govern their affairs." 40 Justice Rehnquist, in an opinion which questioned the plaintiffs' standing, also attacked the sweeping invalidation of all restrictions on abortion during the first trimester of pregnancy. He denied that the right to privacy was involved in these cases and reproached the majority for ignoring the history of the Fourteenth Amendment whose adoption discloses, according to the Justice, no understanding in the minds of the framers that unborn children were not to be regarded as "persons" within its protection. ${ }^{41}$

Three justices concurred in the majority opinion. Chief Justice Burger, displeased with the dissenting Justices' wide interpretation of the majority opinion, rejected the contention that the rule in the cases permits abortion on demand. Justice Douglas, hedging against a too-narrow interpretation of the rule and meeting Justice White's argument about the ordering of priorities between fetus and mother, found Georgia's statute constitutionally defective precisely "because it equates the value of embryonic life immediately after conception with the worth of life immediately before birth" and because the statute fails to include the psychological as well as the physical "health" of the woman as a permissible reason for the right of a woman to interrupt her pregnancy prior to viability. ${ }^{42}$ In Douglas' view, the right of a woman to procure an abortion was well within the marital privacy cases on contraception. The concurring opinion of Justice Stewart was a reluctant acceptance-a capitulation following his long resistance, beginning with the Connecticut Birth Control Case, to the doctrine of substantive due process-of the prevailing view that social policy is now subject to judicial review on substantive grounds. ${ }^{43}$ Rather than scouring the Constitution's hidden recesses for a nonexistent right of personal privacy, he squarely held on the basis of his reading of the precedents that the right of a woman to procure an abortion is part of the "liberty" protected by the Due Process Clause of the Fourteenth Amendment. ${ }^{44}$

39. 410 U.S. 179, 221-222 (1973).

40. Id. at 222 .

41. 410 U.S. $113,172-177$ (1973).

42. 410 U.S. 179, 209-221 (1973).

43. Griswold v. Connecticut, 381 U.S. 479 (1965).

44. 410 U.S. $113,167-171$ (1973). 


\section{B. The German Decision}

On 25 February 1975, after eight months of judicial deliberation, the Federal Constitutional Court invalidated § 218a of the Abortion Reform Act and in effect directed Parliament to reestablish abortion as a crime under the Penal Code. Until the enactment of a valid law, the Court announced that the following rules would govern German public policy on abortion: first, abortion would be permitted during the first twelve weeks of pregnancy under $\S 218 \mathrm{~b}$ of the Reform Act for medical or eugenic indications; second, the termination of pregnancy by a licensed physician during the first twelve weeks after conception would not be punishable if the pregnancy resulted from a criminal assault; finally, the courts would have discretionary authority to withhold criminal sanctions with regard to the termination of pregnancy by physicians during the first twelve weeks in those situations where abortion is the only remaining measure reasonably expected to relieve pregnant women of a "grave hardship." 45

In striking at the heart of the Act, the Court invoked Art. 2, § 2, of the Basic Law, which says: "Everyone shall have the right to life and to the inviolability of his person," what the Court calls an "objective value decision"-indeed the most fundamental value-of the German Constitution. When read in tandem with Art. $1, \S 1$, directing the state "to respect and protect" the dignity of man, Art. 2 incorporates an affirmative duty on the part of the state to secure and preserve human life. In sharp contrast to the U.S. Supreme Court, the German tribunal met head-on the question of when human life begins: "Life in the sense of the historical existence of a human individual exists according to definite biological-physiological knowledge in any case from the 14th day after conception." 48 The Constitutional Court likewise rejected the notion, accepted by the Supreme Court, that the human fetus is divisible into three equal parts signifying gradation of personhood or humanness. "The process of development which has begun at that point in time is a continuous process," said the Court, "which cannot be sharply demarcated and does not allow a precise division of the various stages in the development of human life." 4 Thus the Basic Law's command to respect human life-a command likewise reflected in the abolition of capital punishment under Art. 102-fully extends to the fetus within the mother's womb.

45. 39 BVerfGE 2-3 (1975). The Court's authority to issue such orders' or regulations is derived from BVerfGG $\S 35$. It provides: "The Federal Constitutional Court is authorized to designate who shall implement its judgment; in individual cases it may also regulate the manner of its execution."

46. 39 BVerfG 37. The German text reads: "Leben im Sinne der geschichtlichen Existenz seines menschlichen Individuums besteht nach gesicherter biologisch-physiologischer Erkenntnis jedenfalls vom 14. Tage nach der Empfaengnis (Nidation, Individuation) ..."

47. Id. 
Broadly interpreting Art. 2, the Court construed "everyone" as "everyone living," meaning "unborn life" as well as "born life." That "developing life" or "germinating life" is indeed protected by Art. 2 the Court found abundantly supported in the deliberations leading to the Basic Law's adoption. ${ }^{48}$ Indeed, the Court found buried in the legislative history of the Act an assertion by its main supportersthe Social and Free Democratic Parties-that the "legal value of unborn life is to be respected in principle equally with that of born life." 40

If this motivation was predominant, why then did the Court strike down the statute? Because, according to the Justices, the state failed adequately to balance the interests of the unborn child with those of the mother. The Justices acknowledge that pregnancy falls within that sphere of private relations constitutionally protected by Art. 2, $\$ 1$, of the Basic Law, which says: "Everyone shall have the right to the free development of his personality in so far as he does not violate the rights of others or offend against the constitutional order or the moral code." As this wording indicates, the free development of personality is a qualified right and in the case of pregnant women, note the Justices, it is qualified by the existence of another life about to become "an independent human being." The Court thereby rejects any theory which would treat the decision of a woman not to become pregnant in the first instance on the same level of constitutional protection as her decision to destroy a fetus once pregnancy has occurred. "A balance which guarantees protection of unborn life and secures the right of a pregnant woman to procure an abortion is not possible," declares the Court, "since the termination of pregnancy always means the destruction of human life."so

Yet the Court is not prepared to rule that the Basic Law requires the protection of unborn life regardless of the cost to the mother. Some balancing between the rights of mother and fetus is permissible, even while the Court notes-majority and minority justices alikethat under the Basic Law "dignity" as used within the meaning of Art. 1 ("The dignity of man shall be inviolable") inheres equally in born and unborn life and is no more contingent on a human being's consciousness of it than on his physical ability to preserve it. ${ }^{51}$ Hence developing human life has dignity, and this dignity must be taken into account, especially in the light of the developing fetus's inability to defend itself, when a pregnant woman's claim to the protection of her own dignity would result in terminating the developing life within her.

\footnotetext{
48. 39 BVerfG 38-41.

49. Id. at 40-41.

50. Id. at 43 .

51. Id. at $42-43$.
} 
Accordingly, when balancing the right of the mother to the free development of her personality (Art. 2, $\S 1$ ) and the right of the unborn child to life (Art. 2, § 2), the Court insists that "both constitutional values be perceived in terms of their relationship to 'human dignity,' which is the heart of the political value system under the Constitution." 52 The rights of the unborn child and mother may be balanced, emphasize the Justices, presumably in certain cases to the ultimate detriment of the unborn child, so long as the rightful claims of both are pondered within a framework-clearly demanded by the Basic Law-of respect for the supreme value of human life.

At issue in this constitutional litigation is whether a life-regarding framework of evaluation is provided by the counseling provisions of the Abortion Reform Act. Under Art. 1 of the Basic Law the state is obligated to respect and defend the dignity of man. This duty of the state, declares the Court, is "comprehensive" (umfassend), for it not only proscribes state infringement upon "developing life," but also requires the state affirmatively to protect such life against illegal assault by private parties, including the pregnant woman herself. To defend human life as the ultimate value upon which all other rights depend is thus a fundamental responsibility of the legal order under the Basic Law. ${ }^{53}$

But simply to assert that the supreme value of human life is at stake is to beg large questions. Why are penal sanctions required to safeguard unborn life? And which governmental body or state agency shall be entrusted with this fundamental responsibility? The Court conceded that it is the legislature's responsibility ordinarily to determine the means by which fetal life is to be protected, subject only to the recognition that in the first instance developing life "is entrusted by nature to the protection of the mother."54 Minimally, in the Court's view, the state must seek to reinforce the mother's own determination to protect unborn life, even if that requires the enactment of social welfare measures to support a private decision to preserve the fetus. ${ }^{55}$

The Court does not argue that the right of the unborn child to life must always prevail over the right of the mother to self-determination. Nor does it insist that a law protecting post-natal life apply with equal rigor to pre-natal life. The Justices acknowledge that under the Basic Law the unborn child's right to life may impose a burden upon the mother far in excess of the normal travail associated with pregnancy. They concede that penal measures are an inadequate re-

52. Id. at 43. See also 34 BVerfGE 202, 223 (1974).

53. Id. at 44 .

54. Id. at 45.

55. Id. at 50 . 
sponse to situations where pregnancy leads to "grave hardship." deed, a proper balancing of rights requires the state to respect a morally conscious decision to terminate a pregnancy whose continuance would seriously and unreasonably impinge upon the ability of a woman to preserve her own personhood. In removing such cases from the reach of the criminal law however the state must not neglect its duty to protect life; indeed the state is obligated to admonish the pregnant woman of the necessity to preserve the right to life of the unborn, to encourage her to continue the pregnancy, and to support her through practical aid in cases of special difficulty. In all other cases, say the Justices, abortion must remain a punishable offense within the German legal order for the very reason that when the termination of pregnancy results from mere whim or is unmotivated by a severe condition of distress, it assumes the character of an arbitrary act clearly subversive of the highest value of the Basic Law. But even here, the decriminalization of abortion is justified under the Basic Law only when other equally effective sanctions are applied and only when the law clearly marks abortion as an illegal act.

In the Court's mind, the Abortion Reform Act neither satisfied these criteria nor the level of protection demanded of the state under Art. 1 and 2 of the Basic Law. The Justices found $\S 218 \mathrm{a}$ of the Reform Act constitutionally defective, first, because it failed expressly to embody an official disapproval of abortion during the first twelve weeks of pregnancy and, second, because the counseling plan failed to incorporate a pronounced pro-life orientation. When read together with a supplementary statute, enacted after Parliament's approval of the Reform Act, extending the coverage of the state's obligatory health insurance program to the costs of an abortion, § 218a was considered to be an unlawful encouragement to women wishing to terminate their pregnancies. A valid abortion policy, suggested the Court, must affirm the dignity of unborn life. Indeed a formal statutory condemnation of abortion is necessary to foreclose any inference that the destruction of fetal life during the first twelve weeks of pregnancy is morally or legally a permissible act.57 In ordinary circumstances, noted the Court, "abortion is an act of killing that the law is obligated to condemn." 58

Yet the state is not absolutely required to protect unborn life through penal sanctions. "The decisive factor," said the Court, "is whether the totality of measures protecting unborn life, be they sociolegal or penal in character, is a real safeguard corresponding to the

56. Id. at 48. By "grave hardship" the Court is referring to a severe condition of social, economic, or psychological distress.

57. Id. at 53.

58. id. at 46 . 
importance of the legal value to be secured."50 On the other hand, punishment must be exacted for the procurement of an abortion if no other means is adequate to protect the life of the unborn child. The penal sanction must be proportionate to the legal value threatened with extinction. Thus, as a general principle, "the elementary value of human life requires criminal law punishment for its destruction."

Even a statutory affirmation of the sanctity of unborn life would have been insufficient here because of other fatal defects in the counseling plan under the Abortion Reform Act. Although a woman is required to go to a counseling center and confer with a physician, she -in the Court's reading of the statute - effectively has the option under the Act of destroying the fetus no matter what the reason. Moreover, the plan provides no assurances that the woman will be motivated to carry on her pregnancy. Informational services alone, imparted neutrally by a counseling center, are not sufficient. Nor is the advice of physicians adequate; they would be functioning outside of their expertise when acting as counselors, for they are not trained to proffer professional advice or help in cases requiring an assessment of social need. Indeed, the very physician consulted by the woman wishing to abort a fetus is entitled under the Act to give the required counseling; such a person, the Court surmises, is not likely to work toward the goal demanded by the Constitution. ${ }^{61}$

To satisfy the spirit of the Basic Law, hinted the Justices, the counseling centers themselves would have to be prepared to provide material relief, moral encouragement, and other forms of direct assistance to pregnant women. ${ }^{62}$ Positive programs of this kind might in the eyes of the Court begin to approach the threshold of constitutionality. Whether such agencies would in fact meet constitutional standards was not decided in this case, however. Actually, the thrust of the case is to affirm the necessity of penal sanctions if unborn life is to be adequately safeguarded under the German legal order.

As noted earlier, the Abortion Reform Act was predicated on the notion that preventive measures would be more effective in protecting fetal life than penal sanctions. But it was the Justices' conviction that the inadequacy of the old law consisted mainly in its failure to discriminate between abortions arbitrarily procured and those warranted by legitimate indications, causing a rising number of illegal

59. Id.

60 . Id. at 47 .

61. Id. at $62-63$.

62. Id. at 61 . Counseling centers so equipped were actually recommended by 16 criminal law scholars in an "Alternative Draft" considered by Parliament and which, according to the Court, was actually the basis of the counseling idea. 
abortions. The Abortion Case would now happily end this confusion and put the state on notice that certain terminations of pregnancy are clearly criminal acts demanding prosecution and punishment.

The Court also seemed impressed with predictions, buttressed by statistics concerning the effects of liberal abortion policies in England and East Germany, that if the Abortion Reform Act were validated the incidence of abortions would rise appreciably. The Court was cognizant of the trend toward more liberalized abortion policies in other western countries and cited the examples of Sweden, Austria, England, and France. However, disregarding the fact that these policies were sharply controverted, the Justices pointed out that the legal standards of these countries do not apply to West Germany. ${ }^{63}$

The Court closed its argument by noting that the Basic Law must be understood "in the light of the historical experience and the spiritual-moral confrontation with the system of National Socialism," which stripped men of their dignity and denied the value of human life. Out of the death and destruction of the Nazi era arose a new Constitution-the Basic Law-which reaffirmed "human life" as the highest value of the political order. Moreover, the Federal Constitutional Court was created to insure that this value and other fundamental principles of the Basic Law would be observed by all organs of the State. Thus, in nullifying the Abortion Reform Act, the Court was doing nothing less or more than upholding the Republic's Constitution. ${ }^{64}$

The Abortion Reform Act was invalidated by a 6 to 2 vote of the First Senate of the Federal Constitutional Court. Justices Wiltraut Rupp v. Brünneck and Helmut Simon wrote a common dissenting opinion. The minority opinion does not take issue-indeed it affirmed -the majority's conclusion that human life is a primary value of the legal order and that there is a constitutional duty on the part of the state to protect unborn life. Striking the same note as the dissenting opinions in the American cases, the minority rebukes the Court for ignoring the principles of judicial restraint by substituting its judgment of how best to protect the value of human life for that of the legislature. The question is not whether but how the value of human life is to be protected, remark the two Justices. "This question," they insist, "is a matter of legislative responsibility." 65

The minority argument proceeds as follows: the traditional role of the Federal Constitutional Court has been one of protecting the rights of citizens against state encroachment. But here, in an unprecedented step, the Court seizes upon an objective value decision of the

63. Id. at 66-67.

64. Id. at 67.

65. Id. at 69 . 
Basic Law-namely the state's duty to protect human life-as a basis for requiring the legislature to criminalize abortion and therefore effectively to invade the sphere of personal liberty. ${ }^{60}$ This is contrary to the spirit of the Basic Law and at variance with the original intent of the framers. While required constitutionally to justify the imposition of a criminal penalty for certain conduct, the legislature is under no obligation to justify the replacement of a criminal statute with a social policy deemed more effective than punishment as a means of realizing a given constitutional value. The principles of political democracy and separation of powers place such a decision squarely in legislative hands. Furthermore, it is a fundamental misconstruction of the Basic Law to suggest that any particular solution to a social problem is constitutionally required ${ }^{67}$ The social system is being ordered here, and to transfer this function from the legislature to the judiciary is to convert the Court into a "political arbitration board for choosing between alternative legislative proposals." 68 This is not to say that the Court is never justified in reviewing legislation implementing or promoting an objective value of the Constitution, for the "Court could oppose the legislature when the latter has completely disregarded a value decision or when the nature and manner of its realization is clearly defective." reasonable, having been adopted after an exhaustive parliamentary investigation, and fully consonant with the policy of other "western civilized states."70

The minority chided the Court for paying insufficient attention to the complexity of the social problem surrounding abortion. Social change and changing social values (abrupt and direct in the area of sexual morality), the high incidence of illegal abortions, the unenforcibility of existing penal sanctions, and the discriminatory effect of not enforcing these sanctions are among the problems addressed by the

66. Id. at 71. It is important to note the customary distinction in German constitutional law between objective values and subjective rights. Both are derived from the list of fundamental rights in the Basic Law (Art. 1 through 19). Objective value decisions (objective Wertentscheidungen) are generally norms of political order which govern the exercise of state power; they require affirmative action (actives Handeln) by the state on a continuing basis since the construction of a socially just political order is a permanent task (ständige Aufgabe); as such this duty falls naturally and logically, under a system of divided power, to the legislature. Subjective rights, called "defense rights" (Abwehrrechte) by the two justices in the minority, are those which individual persons seek to vindicate against incursion by specific state actions; they are rights with an identifiable content; most notably, they are rights amendable to judicial resolution because of the availability of concrete standards of judgment developed over time on a case-by-case basis.

67. 39 BVerfG 71-73 (1975).

68. Id. at 72 .

69. Id. at 73 .

70. Id. at 69 . 
legislature. On the basis of its findings, the minority noted, the legislature sought to structure a workable remedy for protecting unborn life. But that remedy was also fashioned in awareness of the moral dilemma confronting women who consider abortion as a means of escaping mental strain or social hardship. Here the "uniqueness of the interruption of pregnancy," as opposed to other ways of endangering life, is stressed. ${ }^{71}$ The destruction of a fetus in the early months of pregnancy is of a different order than ordinary homicide, for the latter can be deterred in no other way than through criminal law. It is the unique unity of "actor" and "victim" that may warrant other than criminal means to preserve unborn life. ${ }^{72}$ The objective values of the Basic Law do not preclude the legislature from devising measures to protect life that are based on the traditional distinction, rooted in European legal history and the canon law of the nineteenth century, between born and unborn life. Furthermore, the mother's unique relationship to the fetus requires an immense investment of psychological and physical energy if a child is to be cared for adequately. It is nature which tells a mother that she must secure and protect the life of the child en ventre sa mere. Hence a criminal statute is not necessary "by nature" (von Natur aus) to secure protection of unborn life and, more importantly, may not be the most effective way of achieving this objective.

Justice Rupp von Brünneck (the only woman on the Court) introduces a female perspective into the minority argument by her reference to the "natural feelings of the woman," w3 which in her view is legally relevant to the legislature's decision to adopt a "term" rather than an "indications" solution to the abortion problem. The argument is psychological and refers to a "growing maternal relationship" and "corresponds to different embryonic stages of development."74 Her point is that this relationship is far stronger in the later stages of pregnancy than in the first trimester. Thus she regards the equating of an abortion in the early weeks of pregnancy with intentional murder as morally naive and legally untenable. The argument is even rooted in theological considerations, for she supports her view by reference to canon law and the theory of ensoulment, which in the 19th century held abortion performed up to the 80 th day after conception to be free from punishment. ${ }^{75}$

Still, in the end, the objective of the statute is to protect life and the burden is upon the court to show that the Abortion Reform Act is deficient in this respect. The minority points out that the legal

\footnotetext{
71. Id. at 78 .

72. Id. at 79 .

73. Id. at 80 .

74. Id. at 81 .

75. Id.
} 
protection of life is never complete or foolproof-a trivial observation since the same could be said of any area of law-and that the counseling scheme of the Reform Act has weaknesses. But then any solution to the problem is likely to be at best a "patchwork" (Stückwerk). The old criminal law was a patchwork; the new Reform Act is a patchwork; but at least it is based on the hope that more rather than less protection for life will be the result. ${ }^{75 a}$

\section{The Abortion Cases: An Analytical Overview}

Let us restate the main constitutional rulings and principles of the German and American abortion cases. The American case holds that the right to privacy, founded upon the Fourteenth Amendment's concept of personal liberty, is broad enough to encompass a woman's decision whether or not to terminate her pregnancy. A zone of privacy is created within which the decision to procure an abortion is exclusively that of the pregnant woman and her physician. Accordingly, the state has no legitimate interest whatever in preventing abortions from occurring within the first trimester of pregnancy. Its only interest is seeing to it that abortions are performed under circumstances that insure adequate surgical procedures and care for patients. Yet the right to procure an abortion is not absolute, and so, following the first trimester of pregnancy, the state may begin to assert important interests in maintaining medical standards. It may assert these interests because an abortion performed in the second trimester is a greater medical risk than one performed in the first trimester. It is only in the last trimester, when the fetus becomes viable and potentially able to survive outside of the womb, that the state may promote its interest in protecting future life, but even during this period the unborn child may be destroyed, medical standards permitting, to preserve the life or health of the mother. What we have here is a constitutional policy on abortion based on the Court's conclusion that a fetus or unborn child is not a "person" within the meaning of the Fourteenth Amendment.

The German Case holds that "developing life" in the womb is an independent legal value protected by Art. 2 of the Basic Law. Life within the meaning of the Basic Law begins on the fourteenth day after conception, approximately at the stage of implantation. Abortion after that stage of development is an act of killing and the law must so indicate. Under the Constitution, the state is duty-bound to protect and foster this life-i.e., the fetus or unborn child in utero-

75a. Since this article was written, the Bundestag has amended $\S 218$ bringing it into line with the Court's directive. The new version of $\S 218$ provides for a comprehensive counseling system for women contemplating abortion. See Fünfzehntes Strafrechtsänderungsgesetz of 18 May 1976, BGBI. I 1213 (1976). 
and under no circumstances is the state permitted to destroy this life. The affirmative duty of the state to protect the fetus must be exercised even against the wishes of the mother. Thus, the right of the child in the womb generally takes precedence over the right of the pregnant woman to self-determination or to the free development of personality. It is not absolutely necessary that criminal law be used as the sole instrument of protecting fetal life; measures other than punishment are permissible. The crucial requirement is that the totality of measures designed to protect unborn life be appropriate to the significance of the legal value safeguarded by the Constitution. If that value can only be protected by the threat of punishment, then punishment is indeed constitutionally required. Yet, the Basic Law does not require extraordinary sacrifice on the part of the woman, nor does it imply that the woman's constitutional right to self-determination is wholly subordinate to the welfare of the fetus. Thus, a pregnancy may be terminated if necessary to protect the woman's life or to guard against the serious impairment of her health. In addition, abortion is free of punishment in those situations where the woman can be expected to undergo serious social hardship. It is clear that such hardship must be out of the ordinary and far in excess of the burdens ordinarily associated with pregnancy. Finally, any counseling system designed for women contemplating abortion must incorporate a positive attitude toward life and seek to persuade and, if necessary, materially to help women see their pregnancies through.

\section{A. Legal Cultures}

How shall we analyze these two decisions? An explanation of their differing doctrinal positions requires some consideration of the legal culture and socio-political values of the two countries, especially West Germany. The socio-political values to which we refer are clear enough and will be discussed further below. The concept of "legal culture" is inexact and rather limited as an explanatory device; nevertheless, if cautiously employed, it can be a useful analytical tool. Here we use the concept of legal culture to describe "a set of deeply rooted, historically conditioned attitudes about the nature of law, about the role of law in the society and the polity, about the proper organization and operation of a legal system, and about the way law is or should be made, applied, studied, perfected, and taught."76

Clearly there is no space here to explore in detail these several aspects of Germany's legal culture. But we will mention a couple of ideas on law and the judicial role that loom important in German legal theory and which seem relevant to this analysis. First, owing in part to the 19th century movement for codification of German pri-

76. Ehrmann, Comparative Legal Cultures 8 (1976). 
vate law and in part to the intense drive for a powerful national state, law has come to be regarded as a highly unified and logically arranged system of rules governing nearly every aspect of human relations. In this view, law is architectonic; it "texturizes" the entire society, giving it unity of direction and purpose. This conception of law is one reason the state stands out as a rich and living reality in 19th century German jurisprudence. It is also the reason why the Rechtsstaat (law state) is a pivotal concept in German constitutionalism, embodying the notion of equal justice under law.

Under the taught-tradition of German law, law is exclusively statutory in nature, and it is the solemn duty of an independent judiciary to apply that law in strict conformance with the legislative or, more accurately, "general" will. The taught-tradition has also influenced the process of constitutional interpretation in West Germany and judicial role perceptions. German justices tend to be less sociological in their approach to constitutional interpretation than their counterparts on the American Supreme Court. The Basic Law's meaning is to be discerned from the literal text of the Constitution read in the light of the Founding Fathers' intent. Those justices who take a broader view of their role tend to emphasize the objectivity of the judicial decision-making process. Consider the following remarks by former Justice Gerhard Leibholz:

In the procedure in which it is to be determined whether a statutory norm is in conformity with the Constitution or not, we are concerned with an objective procedure. Corresponding to this characteristic of the norm control procedure, the declarations of the Federal Constitutional Court of Germany have an effect erga omnes. It is consequently not surprising that the Court decisions, in so far as they contain a determination that a law is not (or is) in conformity with the Basic Law or other federal law, are published by the Federal Minister of Justice in the Bundesgesetzblatt (Federal Gazette). In other words, the decisions of the Federal Constitutional Court have statutory force. In addition, such decisions claim a fundamentally retroactive effect. They apply ex tunc and not ex nunc. The decision on unconstitutionality of a statute by the Federal Constitutional Court of Germany results, in principle, in its absolute nullity . . . .

This norm control is, therefore, of basic importance for the entire constitutional jurisdiction, for under it the ancient tension between the law of nature and positive law-between justice and law-arises. With the help of a constitutional examination of statutes, the norm control system is designed to counter the point of view that "right" can be fully incorporated in a statute. In the certainty that there is a higher law which finds expression, in particular, in the catalogues 
of basic rights in the constitution, constitutional norm control finds its ultimate justification. ${ }^{77}$

The emphasis here upon legal certainty is strong and explains why the authority to nullify legislative statutes is vested exclusively in the Constitutional Court; it also explains the high value Constitutional Court Justices attribute to unanimity on the Court, even though since 1971 the Justices have been legally empowered to publish dissenting opinions. (The Abortion Case is one of those rare instances in which First Senate Justices have published their dissenting views.)

While the legal order broadly reflects community feeling and values-the Volksgeist according to Savigny-constitutional interpretation in West Germany does not respond to the immediate "felt necessities" of the time. Those "felt necessities," whatever they may beand they are not manifest in the abortion dispute-cannot be allowed, in the German view, to nullify or attenuate the central values proclaimed by the constitution. The German decision mentioned two elements of contemporary experience, the widespread incidence of illegal abortion and the Nazi slaughter of defenseless and innocent persons; but in the end these considerations seemed not to loom very large in the reasoning of the Court, although the Court did note that the Founding Fathers had the Nazi experience in mind when they included a right to life in the Basic Law.

\section{B. Religion}

Students of the American judicial process, particularly those of the behavioral persuasion, would be inclined to find the causes of the Abortion decision in the background characteristics and personal beliefs of the German Justices. Indeed one might suppose, as has been suggested, that the German Court's mind was influenced by the religious affiliation of the Justices and particularly by the Catholic presence on the Court. Yet only three of the eight Justices who decided the case are Catholics. Exactly half of the Justices in the majority, including President Ernst Benda, who occupies a crucial place in the decisional process, are Protestants. It might be added that the principles of the Abortion Case are incompatible with the prevailing view among Catholic theologians, which holds that ensoulment takes place with fertilization, whereas the Court held that the fetus assumes the character of personhood at the point of implantation, which occurs fourteen days after conception. In addition, the Court held that abortions are constitutionally permissible in cases of severe hardship (social indications), whereas the prevailing Catholic theological position holds that the direct and purposeful destruction of the fetus is never

77. Leibholz, "The West German Constitutional Court," in McWhinney \& Pescatore, Federalisme et Cours Suprèmes et L'integration des Systèmes Juridiques 57 (1975). 
permissible. Ironically, it was the minority opinion that appealed to theology and canon law in partial support of its conclusion that the destruction of the fetus in the early months of pregnancy does not constitute conduct deserving of criminal punishment.

Whatever the personal beliefs of the Justices, the German decision is distinguished by the fact that it does not explicitly rely upon the theology of any particular denomination or religious tradition. In the main body of the Court's opinion there is no reference to theological thinking or religious belief. Rather, constitutional reasoning is the predominant mode of analysis and the main strength of the German decision; the Court's argument is based exclusively on its analysis of legislative history, constitutional language, judicial precedents, and the intent of the Constitution's framers. The Court did not find any utility or relevance in reciting, as did the U.S. Supreme Court, the history of religious or philosophical reflection about the beginning of life. Biological knowledge and human experience were, for the German Court, sufficient to decide this case. "Life in the sense of the historical existence of a human individual," to reiterate the Court's argument, "exists according to definite biological-physiological knowledge in any case from the fourteenth day after conception."78

The terms "life" and "human dignity," which appear in the text of the Basic Law, were of course interpreted in the light of the nation's experience and culture, which obviously includes religious influences. But then constitutionalism itself has an ultimate religious basis. Karl Friedrich teaches that the very idea of "constitutionalism is rooted in certain basic beliefs, the belief in the dignity of man and the belief in man's inclination to abuse power. These beliefs rest upon religious convictions."7" Few American or German Justices would deny the religious dimension of constitutionalism. The point to be made here is that this religious dimension is ultimate rather than proximate and broadly cultural rather than narrowly denominational. And so, when the German Justices probed the concept of "human dignity" to discern the juridical meaning of "life," they were engaging no more and no less in religious reflection than was Justice Brennan when he asserted in Furman v. Georgia that capital punishment is "inhuman" and fails to "comport with human dignity," or when Justice Marshall opined in the same case that it offends the "conscience of society." 80 Or, to put the matter differently, the presuppositions of Roe v. Wade are no less religious than those of the German Abortion Case. After all, the value of privacy is squarely rooted in the historical belief in man's spirituality, out of which grew a theory of personal autonomy.

78. $39 \mathrm{BVerfG} 37$.

79. Friedrich, Limited Government: A Comparison 123 (1974).

80. 408 U.S. 238 (1972). 


\section{Social Philosophies}

A more plausible explanation for the German decision is to be found in certain normative aspects of the Basic Law. The Constitution might be said to be normative in the sense that it protects certain kinds of values and community interests. The Basic Law embodies a conception of political order that includes an ethical minimus consensus rooted in the moral tradition of the West. Whereas American constitutionalism emphasizes a rugged individualism in the exercise of personal freedom, German constitutionalism has a larger communitarian thrust with a corresponding limitation upon the exercise of political freedom. This difference between American and German constitutionalism is one of emphasis, yet important to an understanding of the varying constitutional policies of the two countries.

The argument is in need of amplification. If we accept here the conventional "Madisonian" view of American constitutionalism, we will regard the political order as a democracy unencumbered by any substantive definition of the public interest and encouraging a pluralism of private interests and moral persuasions. Politics is a method by which group interests are served and freedom is a value primarily in the service of the individual. In this sense, American constitutionalism fails to incorporate a specific notion of the common good or a concept of authority responsible for directing men toward goodness.

The German notion of freedom, on the other hand, if this interpretation of the Constitutional Court's jurisprudence is correct, includes the classical proposition that men fulfill themselves in community with others. There is of course a private sphere which the Basic Law protects. Certain rights of the human person are beyond the reach of the state, for human dignity can subsist, in the modern German constitutional view, only when men are allowed to achieve moral freedom and to act on their moral convictions. But the Constitution sets boundaries to the exercise of freedom. For example, "[e]veryone shall have the right to the free development of his personality," but only "in so far as he does not violate the rights of others or offend the constitutional order or the moral code" (Art. 2, \ 1). Freedom of speech is likewise "limited by the provisions of the general laws, provisions of law for the protection of youth, and by the right to the inviolability of personal honor" (Art. 5, \ 2). Freedom to teach "does not absolve from loyalty to the Constitution" (Art. 5, $\uparrow 3$ ). The right of association is guaranteed, but activities "directed against constitutional order or the concept of international understanding are prohibited" (Art. 9). The one principle which can in no way be encroached upon is "human dignity;" indeed, under the terms of Art. 79, Art. 1 (which proclaims "the inviolability of man's dignity") it is beyond Parliament's amendatory power. The Basic Law also sets up a "so- 
cial" federal state (Art. 20) and underscores the values of marriage and family life while placing mothers under "the care and protection of the community" (Art. 6). Political parties are even instructed to "participate in forming the political will of the people" (Art. 21, italics supplied). These constitutional norms are part of the living fabric of German constitutional law, and fairly accurately reflect values anchored in Germany's social and political traditions.

Free speech jurisprudence offers an illustration of opposing constitutional policies based on the different orientations of the German and American constitutions. Perhaps the strongest current in the broad stream of American free speech theory is the Holmesian "free trade in ideas" view-"that the best test of truth is the power of the thought to get itself accepted in the competition of the market."81 The doctrine is pragmatic and relativistic. Authority does not guide men toward truth; rather the market determines it. And as the market changes, so does truth. In American theory it is not the purpose of political discourse to arrive at truths by which permanently to live; at least those truths may not be incorporated into public law in such a way as to forbid any person or group from attacking them verbally or to foreclose changing them by political means. The individualism implied in the American theory is manifested most clearly by Supreme Court cases effectively immunizing citizens against libel suits arising out of false allegations against public officials and public figures. ${ }^{82}$

The Basic Law requires political man to observe certain traditions of civility when making public utterances. German constitutional theory regards political discourse as an exernise in reasonable debate and as a means of achieving the public good. This requires that men speak the truth. The constitutional value of "personal honor," allied as it is to the concept of "human dignity," permits actions against newspapers and individual citizens for their false and misleading statements about public officials and ordinary citizens. ${ }^{83}$ Indeed, public officials are entitled to special protection under West German libel laws, whereas the reverse is true in the United States. Utterances about public officials in the United States, however distorted or untruthful, may not constitutionally be punished by state libel laws unless it can be shown that the utterances are made with actual malicious intent, which is difficult to prove since to do so one must show that the statement was made "with knowledge that it was false or with reckless disregard of whether it was false or not."84 In Germany,

81. Abrams v. United States, 250 U.S. 616, 630 (1919).

82. See New York Times v. Sullivan, 376 U.S. 254 (1964). See also Curtis Pub. Co. v. Butts and Associated Press v. Walker, 388 U.S. 130 (1967), Garrison v. Lousiana, 379 U.S. 64 (1964), and Gertz v, Robert Welch, Inc., 418 U.S. 323 (1974).

83. See Judgment of 24 Feb. 1971, 30 BVerfG 173.

84. See New York Times Co. v. Sullivan, 376 U.S. 254, 280 (1964). 
free speech is limited by the necessity to preserve public order and to maintain the community's respect for the authority of the state as reflected in the personhood of its high officials. The prevailing American theory of free speech seems consistent with one aspect of the Supreme Court's vision of the political order. As the one-man one-vote principle put forth in the apportionment cases so forcefully shows, ${ }^{85}$ political man is an autonomous agent in an atomistic society, for he speaks for himself and he votes alone.

\section{Abortion Depoliticized}

Thus, although the logic of Roe $v$. Wade leaves much to be desired, the result affirms themes central to a major tradition of American constitutionalism. The effect of that decision is to deny the individual states the right to consider, in shaping their abortion policies, the community's interest in protecting the fetus. In effect, the Court was saying that the question of whether a woman has the right to procure an abortion is not an issue to be effectively considered in the public realm. Thus, oddly enough, free speech cannot be used here to influence the development of public policy. The decision seems perfectly consistent with Madisonian liberalism: the constitutional order is to serve the individual and his interest. In the Supreme Court's Weltanschauung, society is not viewed as fundamentally communitarian in nature. Just as the apportionment cases see the individual voter as an autonomous political agent, Roe $v$. Wade sees the human person as an autonomous moral agent. A woman is thus entitled to separate herself from the community while the community is rendered powerless to act in its common defense for the purpose of safeguarding shared values. It is the Fourteenth Amendment concept of "liberty" that is given overwhelming significance in Roe $v$. Wade, to the virtual exclusion of countervailing considerations that might have been deemed to inhere in the related concepts of "person" and "life." As one writer noted: "The basic assumption of the whole [American] system is very clear: no partial community may impose its substantive vision of the good life on the whole community. On the level of the whole, our unity is formal, not substantive."86

In another sense, however, the Supreme Court did underscore the importance of unity, although not the unity or a community glued together by a moral consensus. In the Court's view, this moral consensus does not exist, and the Court is probably correct here. It appears that Justice Blackmun's dreary recitation of the history of moral

85. See generally Baker v. Carr, 369 U.S. 186 (1962), Wesberry v. Sanders, 376 U.S. 1 (1964), Reynolds v. Sims, 377 U.S. 533 (1964), Avery v. Midland County, 390 U.S. 474 (1968).

86. Schaar, "Some Ways of Thinking About Equality," 26 The Journal of Politics 891 (1964). 
and philosophical thinking about abortion was actually intended to illustrate this lack of consensus. What other reason could there have been for his long prologue to the merits of the case? Surely it provided no theological or scientific basis for dividing pregnancy into three periods and formulating different constitutional rules pertaining to each. The Court's interest seemed to lie in the promotion of social peace-a policy of "live and let live"-best achieved through the constitutional right of privacy.

In a pluralistic society composed of a multitude of belief systems, the Court seems intent on keeping certain issues-those likely to be religiously or theologically divisive-out of the forum of effective public discussion. By not allowing the abortion question to be legislatively determined, the Court has effectively "depoliticized" the issue. If the people's representatives are incapable of acting on an issue after its exhaustion by discussion, it makes no sense, politically, to talk about it. Lemon v. Kurtzman, where the Court invalidated a Pennsylvania statute reimbursing church-related schools for costs of teachers salaries and textbooks in specific secular subjects, is an even clearer illustration of the Court's attempt to "depoliticize" a public issue and, incidentally-to return to the anti-communitarian theme-to erode the significance of religion as an intermediating agency between the individual and mass society. Remarked Chief Justice Burger: "Ordinarily political debate and division, however vigorous or even partisan, are normal and healthy manifestations of our democratic system of government, but political division along religious lines was one of the principal evils against which the First Amendment was intended to protect. The potential divisiveness of such conflict is a threat to the normal political process." 87 Thus is social peace achieved.

This analysis is a rather circumspect way of saying that the result in Roe $v$. Wade not only conforms to the individualistic ethic at the heart of the conventional "Madisonian" interpretation of American constitutionalism, but is also understandable in the light of the pluralistic nature of American society. But then so is German society pluralistic, both religiously and socially, just as there is a wide variety of views in the population on whether abortion should be permitted. On the other hand, the clearly dominant opinion in the German legislature and Federal Constitutional Court is that under the Basic Law the State has a duty to protect unborn life and, what is more, to instruct the people that the taking of unborn life is an offense against human dignity, although these institutions are in disagreement over whether this objective is best achieved by criminalization or decriminalization of abortion. But as the German justices have said on numerous occasions, the Basic Law is not a "value free" Constitution;

87. Lemon v. Kurtzman, 403 U.S. 602, 622 (1971). 
rather, it stands for values that "all state authority" is obligated to protect for the sake of the community or, as the Constitution puts it, "the free democratic basic order."

At the risk of exaggerating the actual difference between judicial role perceptions and methods of constitutional interpretation in West Germany and the United States, we want to suggest that the German decision is also compatible with a legal culture that emphasizes a taught tradition of analytical jurisprudence. In the Abortion Case the German Justices were governed by their own rationality and not by the existing mores of society. The decision did not essentially rest on sociological analysis, although this is not to suggest that a sociological analysis would necessarily have led to a contrary result.

Measured by any logical test that we would wish to apply, the constitutional reasoning in the German Case is more tightly argued and more analytically precise than the argument advanced in Roe $v$. Wade. The German opinion is carefully crafted and composed in measured language, leaving little room for doubt or ambiguity with regard to its meaning. On the other hand, the privacy argument in Roe $v$. Wade is confusing and even contradictory. In the end, the American decision does not lend itself to a clear and unambiguous interpretation. Justice Douglas was even impelled to write a concurring opinion to hedge against a too narrow interpretation of the Court's opinion, studiously avoiding, for example, any reference to "potential life," a concept that Blackmun introduced as a limitation of privacy. Chief Justice Burger, on the other hand, concurred in what amounted to a near dissent by warning against a too broad interpretation of the opinion and by deploring Blackmun's use of current medical knowledge in support of the opinion. Of course, eroded logic is one of the costs of the high value that the justices as well as Americans generally place on the practice of individualized opinion writing on the Supreme Court. In Germany, such personalized expressions of opinion remain a clear exception to the rule. The law-certainly the highest law of the land-ideally speaks with one voice in Germany's legal culture, underscoring both the authority and the unity of the law.

\section{E. The Democratic Process}

Finally, we return to the relationship between the judiciary and the legislature. The American Supreme Court has sought to democratize the political process mainly by standing watch at the ballot box and by insuring that each citizen's vote is counted equally, as well as by protecting free speech. The Court has succeeded in installing what might be called a regime of numerical majoritarianism. It is unconcerned with the quality of political representation once the vot- 
ing is over. And yet, despite its expectation and apparent belief that the one-man one-vote principle will bring public policy more in accord with the will of the electorate, the Court is as ready as ever to strike down legislation no matter how representative of the popular will.

As seen through the eyes of the German Justices, the democratic process is more elaborate than the American conception. Law in Germany is an expression of community feelings and expectations. Those expectations and feelings are crystallized through a democratic political order powered by elections and political parties. Under the Basic Law, the latter "participate in forming the political will of the people" (Art. 21), a will that finds its eventual representation in the will of the state when it is converted and refined into public law by Parliament and other state organs.

One reason why these remarks about the democratic process are relevant is that in the Abortion Case the Court seemed somewhat troubled by the series of quick votes, in the absence of meaningful parliamentary debate, leading to the passage of the Abortion Reform Act in the Seventh Bundestag. The Court seemed distressed by the failure of the Seventh Bundestag to heed the recommendations of the Sixth Bundestag, during which time there was much public and parliamentary debate on abortion, and to abide by the life-regarding principles which, in the Court's view, informed those recommendations. The constitutional ruling in the Abortion Case seems in part to have been attributable to the Court's belief that the political will of the people had not found adequate expression in the Abortion Reform Act. In effect, the Court turned back the clock to where the Bundestag had been in its deliberations when Parliament was suddenly dissolved in 1972 and actually seemed to be inviting the Bundestag to return to the apparent consensus that had been achieved prior to 1972.

The German and American Abortion Cases are both products of political regimes in which judicial review plays a central role in the process of government. The enlightened conscience of a future generation may condemn Roe $v$. Wade in tones that we now reserve for the despised Dred Scott case. Or it may regard Roe $v$. Wade as another step on man's road to freedom. Or men may take a middle position, much like the German Court, and seek a balancing of rights. Whatever the future may hold in this regard, the magnitude of the power that certain constitutional democracies have conferred on their courts of law must be clear to the men of this generation. The reversal of legislative policies as important to society as American state anti-abortion laws and the German Abortion Reform Act is a very serious matter. But the judicial overriding of legislative policy on the ground of constitutionality is apparently one of the prices that citizens within a constitutional regime that confers such authority on its courts are willing to pay. 